\title{
ACCESSING JUSTICE THROUGH VICTIM PARTICIPATION AT THE KHMER ROUGE TRIBUNAL
}

\author{
Kate Yesberg*
}

This article explores the role of victims in the Extraordinary Chambers in the Courts of Cambodia (ECCC) - the forum tasked with bringing leaders of the Khmer Rouge regime to justice. Victims have been afforded broad participatory rights at the ECCC, including the opportunity to be joined as third parties to the trial. These innovations must be applauded. However, the role victims can play in the wider process of national reconciliation remains under-utilised. This article suggests that victim participation can be used to increase public accessibility to the trial to ensure proceedings occupy a more positive, and prominent space in Cambodia's healing process.

\section{INTRODUCTION}

The aftermath of the Khmer Rouge regime is one of history's most tragic displays of postconflict impunity. However, three decades on, the Cambodian Government and the international community have come together to bring a partial and ironic sort of justice to the Cambodian people. ${ }^{1}$ This paper will explore the role of victims in one of the newest international criminal tribunals, the Extraordinary Chambers in the Courts of Cambodia (ECCC), more commonly known as the Khmer Rouge Tribunal (the Tribunal).

In 2006, Boyle stated that the active participation of Khmer Rouge victims at the ECCC would be an essential condition to ensuring impartial and independent trials. ${ }^{2}$ The following pages provide

* Recipient of the 2008 LEADR Prize for Dispute Resolution. Submitted as part of the LLB(Hons) programme at Victoria University of Wellington. I would like to acknowledge the assistance of Alberto Costi and Ian Macduff.

1 Ironic in that until 1990 the Khmer Rouge were recognised as the legitimate Government of Cambodia by the UN; ironic also in that the US dropped 100,000 tons of bombs on Cambodia's Eastern provinces in the late 1960s and early 1970s, causing extreme numbers civilian deaths and, in effect, creating the Khmer Rouge; ironic in that the current Cambodian Government includes many former Khmer Rouge cadre.

2 David Boyle "The Rights of Victims; Participation, Representation, Protection, Reparation" (2006) 4 JICJ $307,310$. 
a short, probing investigation into the current shape of victim participation at the ECCC and how it may achieve these objectives.

Such a discussion is timely. In 2007, the impartiality of the Tribunal came under fire amid "serious allegations of mandatory kickbacks by Cambodian staff to government officials in exchange for their positions." 3 In May 2008, a civil society organisation reported the lack of trust in Cambodia's authorities as one of the major constraints to achieving justice at the ECCC. ${ }^{4}$ The trial phase is now underway, with the first of the accused, Duch - commander of the notorious Toul Sleng prison - appearing before the Trial Chamber on 30 March 2009. It is now time to revisit Boyle's hypothesis and explore the contribution victims can make to increase the integrity of the Khmer Rouge trials.

This article does not attempt to provide substantial comment on the wider issues surrounding transparency and impartiality at the trials, but rather adopts a victim-focused lens to look at the narrower questions of public access and the dissemination of information to victim communities. These issues relate to victims' right to participate in proceedings, and broader reconciliation objectives of the ECCC. However, the hope is that this discussion can make an important contribution to broader debates about transparency and impartiality.

Section II of this article canvases the history, structure and jurisdiction of the ECCC. It also identifies barriers to comprehensive justice, focusing in particular on the need for greater public accessibility to proceedings, and information about the trials. Section III examines the new and controversial participation of victims as civil parties before the ECCC. Section IV amalgamates these discussions by exploring the potential contribution civil party participation can make to the transparency of the Tribunal. It also provides a brief but important caveat on balancing the rights of victims and the accused.

The article concludes that the efforts to afford broad participatory rights to victims must be applauded. However, the lack of public accessibility at the ECCC continues to pose a very serious threat to its success. Consequently, it is essential that all possible avenues to increase transparency are explored. The involvement of civil parties in increasing public access to the trials could be an effective tool.

\section{THE ECCC: CANVASING ITS STRENGTHS AND WEAKNESSES}

Thirty years ago the Khmer Rouge regime decimated the Cambodian population while the outside world turned a blind eye and attempted to wash its hands of the Vietnam War. During the period of Democratic Kampuchea, from 17 April 1975 to 6 January 1979, an estimated 1.7 million

3 Human Rights Watch, World Report 2008 (Seven Stories Press, 2008) 258.

4 The Cambodian Human Rights and Development Association [ADHOC] (May 2008) EC/ICC Justice Project www.bigpond.com.kh/users/adhoc (accessed 20 June 2008) 2. 
Cambodians died from starvation, disease, and execution. ${ }^{5}$ The international community, through the establishment of the ECCC, is now taking actions to condemn these atrocities. However, the ECCC is not a panacea to the immeasurable suffering endured by the Cambodian people three decades ago.

The trial of remaining Khmer Rouge leaders is a long delayed and deeply flawed process. The ECCC is part of a weak and corrupt domestic judicial system and will struggle to insulate itself from these influences. ${ }^{6}$ However, millions of dollars are now being poured into the project, and as such it is vital that a great effort is made to ensure that the ECCC makes the best possible contribution to national reconciliation.

\section{A Establishing the ECCC}

The ECCC is the product of a bilateral agreement between the United Nations and the Royal Government of Cambodia (the Agreement) signed in 2003. In 2004, Cambodia ratified this agreement in passing "The Law on the Establishment of the Extraordinary Chambers in the Courts of Cambodia for the Prosecution of Crimes Committed during the Period of Democratic Kampuchea" (the ECCC Law).

The jurisdiction of the ECCC lies at a unique intersection between international and domestic law, an example of a new breed of 'hybrid' or 'internationalised' tribunal. ${ }^{7}$ The ECCC is part of Cambodia's domestic judicial framework. Each Chamber houses both local and international judges, with a Cambodian majority in each. ${ }^{8}$ Decisions must be reached by a super-majority, requiring the agreement of at least one international judge. ${ }^{9}$ All parties to the trial have access to both national and international legal representation.

The ECCC also has subject-matter jurisdiction over both national and international crimes. ${ }^{10}$ In terms of substantive law, the ECCC has the power to try suspects for the domestic crimes of

5 William Shawcross "Cambodia and the perils of humanitarian intervention" (April 2002) Dissent 48.

6 Human Rights Watch World Report 2008, above n 3. see also Transparency International Global Corruption Report 2007 www.transparency.org: According to this report "[j]udicial officers [in Cambodia] are among the least trusted government officials, and provincial courts among the least trusted institutions, according to a recent opinion survey... political influence affects appointments, case selection and rulings... [and] Judicial opinions are not documented transparently, and judges rarely explain their reasoning or note it in the court record."

7 James Cockayne "Hybrids or Mongrels? Internationalized War Crimes Trials as Unsuccessful Degradation Ceremonies" (2005) 4 Journal of Human Rights 455, 459.

8 The Pre-Trial and Trial Chambers have 3 Cambodian judges and 2 international, and the Appeals Chamber has 4 Cambodian and 3 international judges.

9 A decision requires a vote of 4/5 in the Trial Chamber, and a vote of 5/7 in the Appeals Chamber.

10 Law on the Establishment of Extraordinary Chambers in the Courts of Cambodia for the Prosecution of Crimes Committed During the Period of Democratic Kampuchea 2004, art 3-8. 
homicide, torture and religious persecution. Suspects may also be charged with the international crimes of genocide, ${ }^{11}$ crimes against humanity, grave breaches of the 1949 Geneva Conventions, ${ }^{12}$ destruction of cultural property during armed conflict, ${ }^{13}$ and crimes against internationally protected persons. ${ }^{14}$ It is also required to follow Cambodian judicial procedure except where this is silent, uncertain or incompatible with international principles. The Court may then refer to the relevant international rules. ${ }^{15}$

The Tribunal has temporal jurisdiction over the period of Democratic Kampuchea, from 17 April 1975 to 6 January 1979, and personal jurisdiction over "senior leaders" and "those most responsible" for the atrocities committed during that time. ${ }^{16}$ The Court has to date indicted five persons: Guech Eav Kaing (alias Duch), Noun Chea, Ieng Sary, Ieng Thirith and Khieu Samphan.

It has taken 30 years, but an attempt at bringing justice is finally being made in Cambodia. However, does the jurisdiction of the ECCC provide a foundation which can render comprehensive justice to victims of the Khmer Rouge?

\section{B Barriers to Comprehensive Justice}

The limited personal and temporal jurisdictions, although pragmatic, will restrict the Court's effectiveness in bringing about comprehensive justice and national reconciliation. ${ }^{17}$ By comprehensive justice I mean the ability of the ECCC to garner a full and accurate picture of the Khmer Rouge regime, to hold to account all remaining "senior leaders" and "those most responsible" for their crimes, and to contribute to the wider needs of the victim communities.

The temporal jurisdiction restricts the ambit of the investigations to the official four year reign of the regime. However, the Khmer Rouge committed atrocities both before and after the period of

11 As defined in the Convention on the Prevention and Punishment of the Crime of Genocide (9 December 1948) 78 UNTS 277.

12 Geneva Conventions (12 August 1949) 75 UNTS 31, 85, 135 and 287.

13 Pursuant to the Convention for Protection of Cultural Property in the Event of Armed Conflict (14 May 1954) 249 UNTS 354.

14 As defined in the Vienna Convention on Diplomatic Relations (18 April 1961) 500 UNTS 95.

15 Boyle, above n 2, 308.

16 Law on the Establishment of Extraordinary Chambers in the Courts of Cambodia for the Prosecution of Crimes Committed During the Period of Democratic Kampuchea 2004, art 2.

17 Open Society Justice Initiative, "Recent Developments at the Extraordinary Chambers in the Courts of Cambodia"(May 2008) Monthly Update on the ECCC, 24. 
Democratic Kampuchea. These crimes fall outside the jurisdiction of the ECCC and will consequently go unpunished. ${ }^{18}$

Personal jurisdiction is extended to "senior leaders" and "those most responsible" for the atrocities committed by the Khmer Rough. At the time of writing, the Tribunal had indicted only five people, which may be perceived as woefully inadequate. Particularly as the five charged persons are now elderly people who have been living privileged lives in Cambodia and abroad for the intervening years. In December 2008, a disagreement arose between the Cambodian and international co-prosecutors over the decision to investigate a further six individuals. ${ }^{19}$ The Cambodian Co-Prosecutor has opposed the move, asserting that the "spirit of the ECCC agreement is to focus on only a small group of individuals," that the Tribunal's limited funding does not allow the addition of further defendants and raising concerns that "prosecuting perpetrators other than the highest leaders could harm Cambodia's stability and national reconciliation."20 The international coprosecutor has applied to have the issue resolved by the Pre-Trial Chamber.

While resource constraints will unavoidably limit the ability of the ECCC to try a large number of people, the appropriate equation, according to commentator David Scheffer, should be: ${ }^{21}$

a reasonable number limited by long-term resource availability and a reasoned application of the requirement that defendants be 'senior leaders of Democratic Kampuchea and those who were most responsible' for the atrocity crimes of the Pol Pot regime.

In a recent article in The Economist, Yash Ghai, a former special representative of the UN Secretary General to Cambodia, is quoted as stating that if prosecutors have enough evidence to prosecute, "they have a duty to do so."22 The decision of the Pre-Trial Chamber in this matter will be pivotal in setting the tone of interpretation for the personal jurisdiction of the ECCC, and will no doubt be duly critiqued when the time comes.

The thirty year delay between crime and punishment will also limit the Tribunal's contribution to reconciliation. ${ }^{23}$ The Khmer Rouge leader, Pol Pot avoided punishment and died a free man in

18 Suzannah Linton "New Approaches to International Justice in Cambodia and East Timor" (2002) 84 IRRC 93, 119.

19 See The Court Report: March 2009: www.eccc.gov.kh (accessed 20 June 2008).

20 International Centre for Transitional Justice Q\&A: First trial by Cambodia's Khmer Rough tribunal (12 February 2009) www.ictj.org/en/news/features/2291.html (accessed 6 April 2009).

21 Scheffer, David "How many are too many defendants at the KRT?" The Phnom Penh Post (8 January 2009) www.cambodiatribunal.org (accessed 20 June 2008).

22 "The Court on Trial:Accusations of corruption threaten to discredit the trial of the Khmers Rouges" (2 April 2009) The Economist www.economist.com.

23 Christopher Rudolph "Constructing an Atrocities Regime: The Politics of War Crimes Tribunals" (2001) 55 Int'l Org 655, 664. 
1998. The lapse in time will also have had a negative effect on testimonial and forensic evidence. ${ }^{24}$ Additionally, the geographical seclusion of the trials will prevent the ECCC from occupying a prominent place in Cambodian life. The ECCC is housed in a former military base on the outskirts of Phnom Penh, ${ }^{25}$ making it difficult for most Cambodians to attend public hearings. ${ }^{26}$ However, one of the greatest risks to comprehensive justice at the ECCC is the current lack of transparency in proceedings.

\section{The Case for Public Accessibility}

In 2007, Transparency International concluded that the judicial system in Cambodia remained extremely weak and generally unable to deliver justice to those whose human rights have been violated. ${ }^{27}$ Reports of corruption and the removal or reassignment of cases from trouble-making judges are common. ${ }^{28}$ Despite international involvement in the trials, the ECCC is struggling to detach itself from the reputation of the domestic judiciary.

In the final agreement establishing the ECCC, the UN made considerable concessions to its original demands for an international, impartial and independent tribunal. In 2000, Kofi Annan set out four principles he deemed necessary for the operation of this tribunal: a judicial bench consisting of a majority of international judges, an independent international prosecutor, a commitment from the Cambodian government to arrest any person indicted by the tribunal, and an assurance that the amnesty granted to Ieng Sary (second-in-command after Pol Pot) in 1996 would not bar his prosecution. ${ }^{29}$ These conditions were rejected by Cambodian Prime Minister, Hun Sen. In February 2002, the UN pulled out of the negotiation process after concluding that the mixed tribunal as envisaged "would not guarantee the independence, objectivity and impartiality that a court established with the support of the United Nations must have." 30 However, they rejoined and concluded negotiations in 2003 despite the Agreement continuing to fall short of Kofi Annan's four fundamental principles - the Agreement established a Cambodian, rather than international,

24 See Mohamed Ali Lejmi "Prosecuting Cambodian Genocide: Problems Caused by the Passage of Time since the Alleged Commission of Crimes" (2006) 4 JICJ 300.

The ECCC is a 45 minute bus ride from central Phnom Penh.

Patricia M Wald "Iraq, Cambodia, and International Justice" (2006) 21 Am U Int'l L Rev 541, 552.

Transparency International Global Corruption Report 2007 www.transparency.org (accessed 9 February 2009).

Wald, above n 26, 554.

Shawcross, above n $5,52$.

Shawcross, above n 5, 53. 
majority on the judicial bench, ${ }^{31}$ a prosecution team comprised of both local and international lawyers, rather than an independent international prosecutor, ${ }^{32}$ the Cambodian government is now hesitant to consent to further arrests, and the amnesty granted to Ieng Sary in 1996 is being used as a defence by his lawyers. ${ }^{33}$

Consequently, the UN does not have the same degree of control as it has in the ad hoc tribunals, the International Criminal Tribunal for Yugoslavia (ICTY) and the International Criminal Tribunal for Rwanda (ICTR), ${ }^{34}$ or the hybrid Special Court for Sierra Leone. ${ }^{35}$ The Cambodian elements of the ECCC retain majority control over the judicial bench and the Office of Administration. Serious allegations have been made of mandatory kickbacks by Cambodian staff to government officials in exchange for their positions. ${ }^{36}$ In 2007, the United Nations Development Project undertook a Special Audit of ECCC procedure. Their report, released in June 2007, criticised the ECCC for ineffective monitoring and oversight by the project board, the hiring of local staff who did not meet minimum job requirements, and an unjustified excess in staffing level in the budget. The audit team was also restricted from accessing the files of twenty eight staff members. ${ }^{37}$ While the international community has on numerous occasions withheld funds pending investigations of corruption allegations, the UN does not have the power under the Agreement to commandeer and control the process. The challenges of real and perceived malpractice and partiality at the ECCC are seriously undermining its integrity and ability to provide comprehensive justice and contribute to national reconciliation.

Of particular importance to victims is the lack of public accessibility to trials and associated dissemination of information. At the ECCC, the main barrier to public access is the presumption of in camera proceedings which operates at the pre-trial phase. Pursuant to Internal Rules 56 and 77(5)

31 UNGA "Agreement Between the United Nations and the Royal Government of Cambodia Concerning the Prosecution Under Cambodian Law of Crimes Committed During the Period of Democratic Kampuchea" (22 May 2003) A/RES57/228B, Art 3. [Agreement]

32 Ibid, Art 6.1.

33 Ieng Sary's Submissions Pursuant to the Decision on Expedited Request of Co-Lawyers for a Reasonable Extension of Time to File Challenges to Jurisdictional Issues (7 April 2008) 002/19-09-2007-ECCC-OCIJ (PTC03) (The Defence for Ieng Sary, ECCC).

34 The ICTY was established by UNSC Resolution 827 (25 May1993) S/RES/8271990, and the ICTR by UNSC Resolution 955 (8 November 2004) S/RES/955/2004.

35 Cockayne, above n 7, 469; see www.sc-sl.org. Cockayne describes the Special Court for Sierra Leone as an ad hoc tribunal dumped in Freetown. The UN has retained almost complete control over the judicial bench, with all judges bar three coming from foreign jurisdictions.

36 Human Rights Watch World Report 2008 above n 3,4.

37 United Nations Development Programme "Audit of Human Resources Management at the Extraordinary Chambers in the Courts of Cambodia" (4 June 2007) Report No. RCM0172. 
of the ECCC, judicial investigations and hearings before the Pre-Trial Chamber are also held in camera. In the domestic context, this presumption is justified by factors such as preserving the integrity of the criminal investigation, recognising the sensitivities involved in gathering evidence, and the safety concerns of potential witnesses. This is standard practice in many inquisitorial jurisdictions. ${ }^{38}$ In ordinary criminal trials these factors may rightly outweigh the public interest in open proceedings, particularly in jurisdictions where judicial independence is secure.

However, the specific context of the ECCC must be taken into account in assessing the appropriateness of a presumption of in camera proceedings. First, as discussed above, there is a well-documented lack of trust in the judicial process which the ECCC will have to overcome to earn the confidence of the Cambodian public. A closed process will be viewed with far greater suspicion, making this task incredibly difficult for the Tribunal. ${ }^{39}$

Second, the trial of international criminals in a post-conflict context requires far greater transparency than an ordinary criminal trial. A primary purpose of such trials is to contribute to national reconciliation and collective healing. ${ }^{40}$ Human Rights Watch has stated that "as with other international and hybrid criminal tribunals where widespread public acceptance of the legitimacy of verdicts is crucial, the ECCC's over-reliance on closed sessions may do long-term damage to the court's broader goals." 41 The ECCC should hold meaning for all Khmer Rouge victims. If the process is inaccessible to ordinary Cambodians, it will be impossible for the Tribunal to meet the needs of victims.

The Cambodian people cannot be expected to put their trust in a tribunal whose proceedings they cannot see. Consequently, the adoption of measures to increase public access may be an efficient and effective way to counter suspicions concerning the impartiality and independence of the trials. The ECCC has taken this on board to some extent. Article 12(2) of the Agreement between the Royal Government of Cambodia and the UN states that public access to proceedings should apply at all times, on the basis that it is "not only in the interest of securing a fair and public hearing in accordance with international standards to do so, but also for the credibility of the procedure." 42 Transparency is also enshrined as a fundamental principle of the ECCC in its Internal

38 International Center for Transitional Justice Comments on Draft Internal Rules for the Extraordinary Chambers in the Courts of Cambodia (17 November 2006) www.dccam.org/Tribunal/Documents (accessed 20 June 2008).

39

Ibid, 9.

40 Agreement, above n 31, Preamble.

41 Human Rights Watch Comments on Internal Rules (17 November 2006) www.dccam.org/ Tribunal/Documents (accessed 9 September 2009).

42 International Center for Transitional Justice, above n 38. 
Rules. ${ }^{43}$ It has been affirmed that if trials are to be a means of achieving reconciliation through justice, ordinary citizens must be informed about the judicial process.

The ECCC outreach programme distributes information booklets, posters, and stickers throughout Cambodia. The Tribunal produces a monthly court report which began in May 2008, and issues regular press statements. The ECCC also airs radio segments, with themes such as "everyone can be involved," "it's time to set the record straight," and "only the senior leaders will be tried."44 This is particularly important considering the low literacy rate in rural Cambodia. ${ }^{45}$

There are also many civil society organisations running parallel community education projects. ${ }^{46}$ NGO efforts include raising awareness and information dissemination, gathering and archiving evidence, and assistance with civil party applications and legal representation. Proceedings at the ECCC are also gaining significant media coverage, both nationally and internationally. ${ }^{47}$

Concerns about public accessibility have also been addressed to some extent by the drafters of the ECCC Internal Rules. While a presumption of in camera proceedings does apply at the pre-trial phase, there are a number of exceptions. Rule 77(6) allows the Pre-Trial Chamber, at the request of a judge or party, to open hearings to the public when doing so is in the interests of justice and does not affect public order or any protective measure authorised by the court. Rule 56(2) allows the coinvestigating judges, after consultation with the parties, to release information or allow public access to their proceedings. Similarly, Rule 54 enables the co-prosecutors to provide the public with an objective summary of the information contained in their introductory, supplementary, and final submissions, which are otherwise confidential. It is noteworthy that the co-prosecutors have recently issued a public objective summary regarding their final submission in the Duch case. ${ }^{48}$ These departures from the in camera presumption are commendable and demonstrate commitment to transparent trials.

However, the language of these exceptions is permissive, not obligatory. The transparency of the pre-trial phase is at the discretion of the judges and the prosecution. To date the exceptions to in

43 Extraordinary Chambers in the Courts of Cambodia Internal Rules (Rev. 1) (12 June 2007), r 21 [Internal Rules.]

44 See www.eccc.gov.kh/english/publications (accessed 15 August 2009).

45 The adult literacy rate was $69.6 \%$ in the Cambodia Socio-Economic Survey 2004, www.statsnis.org/SURVEYS/ (accessed 20 August 2009.)

46 See www.dccam.org; www.csdcambodia.org; www.bigpond.com.kh/users/adhoc.

47 See www.cambodiatribunal.com.

48 Public Information by the Co-Prosecutors Pursuant to Rule 54 Concerning Their Rule 66 Final Submission Regarding Kaing Guek Eav alias "Duch" (18 July 2008) 002/14-08-2006/ECCC/OCP (Office of the CoProsecutors, ECCC). 
camera proceedings have been used sparingly. The Pre-Trial Chamber have conducted parts of the hearing of appeals on pre-trial detention orders in public, ${ }^{49}$ and as stated above, the co-prosecutors have released a public objective summary concerning the Duch case. However, civil society in Cambodia and abroad has been dissatisfied with the level of public access at the pre-trial phase. ${ }^{50}$

Of particular concern is that, due to this in camera presumption and the unwillingness of the Court to fully utilise the exceptions, NGOs are struggling to organise close external monitoring of ECCC proceedings. The significance of trial monitoring has been stressed by scholars and various international criminal tribunals. ${ }^{51}$ Linton states that close monitoring of the trials is essential to achieving reconciliation through justice. ${ }^{52}$ However, the issue of trial monitoring has not been as acute in existing international tribunals. Many of these tribunals adopt common law-based procedures where a presumptively public trial phase incorporates the work conducted at the pre-trial phase in civil law proceedings. ${ }^{53}$ However, in recent cases before international jurisdictions, trial monitors have also been permitted to remain in court when proceedings have been closed. This was the case at the Special Court for Sierra Leone whose Rules of Procedure state that "in the event that it is necessary to exclude the public, the Trial Chamber should if appropriate permit representative of monitoring agencies to remain." 54 Similar provisions have been made at the Special Panels for Serious Crimes in Timor Leste. ${ }^{55}$ Trial monitoring has been recognised as an important means through which they can reassure the public that closed sessions are being used appropriately.

In March 2008, civil society groups in Phnom Penh responded to the lack of transparency at the ECCC by issuing the Civil Society Recommendations on Transparency Measures. ${ }^{56}$ The groups affirmed that: ${ }^{57}$

49 Ruling on the Defence's Request For a Public Hearing on the Appeal Against Provisional Detention Order and on the Co-Prosecutors' Request for Redaction of the Defence's Appeal Brief (3 March 2008) 002/19-092007-ECCC-OCIJ(PTC04) (Pre-Trial Chamber, ECCC).

50 See Civil Society Recommendations on Transparency Measures (March 2008) www.cambodiatribunal.org (accessed 3 July 2008); see also Human Rights Watch Comments on Internal Rules above n 41.

51 See Ralph Henham "Theorising law and legitimacy in international criminal justice" (2007) 3 Int'l J L Context 257, 271; Linton, above n 18, 118.

52 Linton, above n 18, 119.

53 The ICTY and ICTR were both established quickly along common law procedural lines. However, the ICC was the product of international collaboration and as such incorporates both common and civil law procedural traits. See Behrens, Hans-Jorg "Investigation, Trial and Appeal in the International Criminal Court Statute (Parts V, VI, VIII)" 6 Eur J Crime Crim L \& Crim Just 4 (1998) 429-441.

54 International Center for Transitional Justice, above n 38, 10-11.

55 International Center for Transitional Justice, above n 38, 10-11.

56 Civil Society Recommendations on Transparency Measures, above n 50.

57 Ibid 1. 
providing information to the people of Cambodia about the work of the ECCC is critical if the court is to meet its goal of combating impunity, serving as an example of independent justice, and helping to heal wounds of the Khmer Rouge period in Cambodia.

The recommendations included greater clarity and better communication between the press, the principals of the court and members of civil society. They also suggested that a presumption of public, rather than private, hearings operate in the Pre-Trial Chamber. The report questioned whether the "legitimate purposes of, and need for confidentiality, actually require the high degree of secrecy currently imposed by the court on the investigation proceedings." 58 Similar concerns were raised by NGOs in 2006 in their comments on the Draft Internal Rules. Human Rights Watch then stated that "[i]n a civil law system where many key decisions are decided during the pre-trial phase it is particularly important that the proceedings be accessible and transparent to the public wherever possible." 59

However, there has been no indication from the ECCC of plans to amend the Internal Rules and provide for a more open pre-trial phase or allow monitors into closed sessions. Consequently, it is necessary to investigate alternative methods for creating a more accessible tribunal. While the civil law context has posed a greater challenge to transparency than in existing adversarial tribunals, it has also made positive innovations regarding the participation of victims. The remainder of this paper will investigate how these innovations may offset the difficulties posed by in camera investigatory proceedings.

\section{VICTIM PARTICIPATION AT THE ECCC}

Victim participation at the ECCC is new, exciting and controversial. In the context of international criminal tribunals, the ECCC provides for the most extensive participation of victims in its proceedings. As at other international criminal tribunals, victims may lay complaints with the Tribunal, be called as witnesses, and seek moral and collective reparations. ${ }^{60}$ Additionally, victims under Cambodian criminal procedure may also be joined as a partie civile or civil parties to the trial and enjoy participatory rights akin to those of the accused.

$58 \quad$ Ibid 2.

59 Human Rights Watch, above n 34.

60 Internal Rules, rr 52 and 24 respectively; anyone may be called as a witness by the ECCC unless Rule 24(4) applies, which exempts any person against whom there is evidence of criminal responsibility. However, Rule 28 enables the Co-Investigating Judges or the Chambers to provide assurance to potential witnesses that the evidence they give will not be used against them in the future. 
The role of victims has come to the fore over the last ten years. Much has been written on the rise of victims at international tribunals but a brief discussion of this development may serve to situate victim participation at the ECCC in its wider context. ${ }^{61}$

The post-WWII Nuremburg trials were the first international effort to "pierce the sovereign veil" and hold individual leaders accountable for crimes against humanity. ${ }^{62}$ The Nuremburg trials were established for the just and prompt trial and punishment of major war criminals and did not address the rights of victims or their participation in the trials. In fact, the prosecution at Nuremburg did not call any victims of the Nazi regime to testify as witnesses, relying solely on the extensive documentary evidence compiled by the regime itself. ${ }^{63}$

However, victims' rights were encapsulated shortly after in 1948 by the Universal Declaration of Human Rights (UNDHR), Article 8 of which states that "everyone has the right to an effective remedy by the competent national tribunals for acts violating the fundamental rights granted him by the constitution or by law." 64 This right is also protected under the International Covenant on Civil and Political Rights and has been upheld by the UN Human Rights Commission. ${ }^{65}$ In 1985, the UN General Assembly adopted the first significant set of international standards on the rights of crime victims in the UN Declaration of Basic Principles for Justice for Victims of Crime and Abuse of Power which states that administrative processes should allow "the views and concerns of victims to be presented and considered at appropriate stages of the proceedings where their personal interests are affected." 66

After a long Cold War hiatus, international criminal justice reappeared in the 1990s with the formation of two ad hoc tribunals established by UN Security Council Resolutions to try those most responsible for crimes committed in the Former Yugoslavia, the ICTY, and the 1994 Rwandan genocide, the ICTR. ${ }^{67}$ At the ICTY and ICTR, prosecutors rely heavily on victim testimony and

61 See William Schabas An Introduction to the International Criminal Court (Cambridge University Press, Cambridge, 2007); Marie-Benedicte Dembour and Emily Haslam "Silencing Hearings? Victim-Witnesses at War Crimes Trials" (2004) 15 EJIL 151; Jonathan Doak "Victims' Rights in Criminal Trials: Prospects for Participation" (2005) 32(2) J L \& Soc 294; Maurice Kouadio N'Dri "Critical Analysis of Victims' Rights Before International Criminal Justice" (LLM Research Paper, University of Pretoria, 2006); Christopher Rudolph above n 23, 664 .

62 Sheri P Rosenberg "Symposium: The Nuremberg Trials: A Reappraisal and their Legacy: An Introduction" 27 Cardozo L Rev 1549, 1550.

63 Maurice Kouadio N'Dri, above n 61, 20.

64 UNGA Resolution 217 LXIII (10 December 1948) A/RES/3/217, art 8.

65 International Covenant on Civil and Political Rights (16 December 1966) 999 UNTS 171, art 2(3); Rodriguez v Uruguay (Communication 322/1988); Bautista v Colombia (Communication 563/93).

66 UNGA Resolution 40/34 (29 November 1985) A/RES/40/34, para 6(b).

67 See above $n 34$. 
eyewitness accounts. ${ }^{68}$ The Statutes and Rules of Evidence and Procedure of each Tribunal provide for various forms of victim assistance, protection, and reparation, indicating that victims have become a part of the international criminal justice agenda. However, despite this recognition, the ICTY and ICTR do not provide for victim participation beyond appearing as witnesses.

The ad hoc tribunals also suffer from severe budget constraints which limit their ability to fully provide for victims. For example, at the ICTY protection is not afforded to witnesses once they have finished testifying at the Tribunal and return home. ${ }^{69}$ This raises serious concerns for the long-term safety of the numerous victims involved in the trial. Similar issues exist at the ICTR. Pursuant to Rule 69 of the ICTR statute, "the prosecution may keep confidential the identity of victims or witnesses who may be at risk of retaliation; however, once under the protection of the tribunal, their identities must be disclosed to the defence."70 In 1996, the UN Human Rights Field Operation in Rwanda "documented more than sixty-four separate incidents in which genocide survivors and their family and friends were killed (227 people) or were injured (56 people) as a consequence of their testimony before the tribunal."71

The Rome Statute of the International Criminal Court, adopted on 17 July 1998, is the first international criminal justice mechanism to provide for direct and active participation of victims in its proceedings. ${ }^{72}$ As well as being a milestone in the fight against impunity, the ICC took a major step towards the recognition and enhancement of victims' rights. While following a common law based procedure, the ICC has been inspired by civil law mechanisms of victim participation. The Rome Statute allows victims to present their views and concerns throughout proceedings when their personal interests are affected "...in a manner which is not prejudicial to or inconsistent with the rights of the accused to a fair and impartial trial." ${ }^{73}$ Victims are not full parties to the proceedings, but they do have the right to participate, the right to legal representation and may also seek reparations.

\title{
A Victims as Civil Parties
}

Inquisitorial traditions recognise victims as key stakeholders in the criminal justice process. Their procedures allow individuals or groups of victims to be joined as civil parties to the proceedings. The role of civil parties is distinct from that of the prosecution, though their functions are similar in that both parties are acting on behalf of their wider communities. Prosecutors act on

\author{
68 Rudolph, above n 23, 664. \\ 69 Rudolph, above n 23, 664. \\ 70 Rudolph, above n 22, 669. \\ 71 Rudolph, above n 22, 669. \\ 72 Rome Statute of the International Criminal Court (17 July 1998) 2149 UNTS 256 [Rome Statute]. \\ 73 Ibid, art 68(3).
}


behalf of the State, and civil parties - particularly in the context of war crimes trials - as representatives of victim communities. The task of the prosecutors is to secure a guilty verdict against the accused, while civil parties in Cambodia are likely motivated by broader goals concerning reparation and reconciliation within their communities. Consequently, the contribution each party makes to the trial will be different.

At the ECCC, civil parties must be victims who have personally sustained a real physical, material, or psychological injury as a direct consequence of the offence. ${ }^{74}$ This limits civil party applications to direct victims of the Khmer Rouge and their heirs. As full parties to the proceedings, civil parties are granted many of the same rights as the accused. Civil parties have the right to be represented by a lawyer. ${ }^{75}$ They may appeal against orders of the Co-Investigating Judges and the Trial Chamber, make applications to the Chambers, call witnesses, and make opening and closing statements. $^{76}$

Internal Rule 23 governs the participation of civil parties. Pursuant to this Rule, the purpose of civil party actions before the ECCC is to: ${ }^{77}$

(a) Participate in the proceedings by supporting the prosecution, and

(b) seek collective and moral reparations.

In particular, civil parties can support the truth-finding efforts of the prosecution. ${ }^{78}$ Every victim of the Khmer Rouge holds a piece of the truth about that dark period and their involvement will greatly increase the ability of the ECCC to create a comprehensive and accurate picture of the period. However, it must be stressed that civil parties are much more than "evidentiary cannon fodder" 79 for the prosecution. As independent parties to the proceedings, civil parties control the extent and form of the evidence they present.

Civil parties can also seek collective and moral reparations at the ECCC, which may take the form of an order to publish the judgment in any appropriate news or other media at the convicted person's expense; an order to fund any non-profit activity or service that is intended for the benefit of victims; or other appropriate and comparable forms of reparation. ${ }^{80}$ Civil parties are not entitled

74 Internal Rules, r 23(2).

75 Internal Rules, r 105.

76 Internal Rules, rr 74 and 105.

77 Internal Rules, r 23(1).

78 ADHOC Comment on the Right of the Civil Party in the Proceedings of the Extraordinary Chambers in the Courts of Cambodia (February 2007) 47 www.bigpond.com.kh/users/adhoc (accessed 9 August 2009).

79 Doak "above n 61, 299.

80 Internal Rules, r 23(12). 
to individual compensation, which indicates the broad motivations behind victim participation at the trials. While participation might satisfy personal desires for revenge or retribution, the goals of civil party participation are to contribute to communal healing and national reconciliation.

Concerns have been raised about the effect that too many civil parties may have on the efficiency of proceedings. ${ }^{81}$ Due to the vast numbers of victims (a whole generation and their children), there is the potential for many Cambodians to become civil parties. To address the issue of efficiency, the Tribunal has focused on organising civil party participation in a way that will effectively accommodate a potentially large number of civil parties. Rules 23(8) and (9) provide for a form of collective or class action. A group of civil parties may choose to be represented by a single lawyer. ${ }^{82}$ The Co-Investigating Judges or the Chambers may also request that a single lawyer be chosen or assigned. This is the approach adopted at the International Criminal Court (ICC). At the ECCC, a group of victims may also choose to collectivise their civil party action by becoming members of a Victims' Association. ${ }^{83}$ By joining a Victims' Association, the victim becomes a civil party to the trial and will be represented by the Association's lawyer.

As a general rule under Cambodian criminal procedure, victims' rights are exercised individually. ${ }^{84}$ The departure from this rule and the adoption of flexible standing criteria at the ECCC demonstrates an awareness of the unique challenges faced by the trials and is a logical means of accommodating large numbers of victims. Collective representation is also beneficial for victims as it allows for cost sharing and greater collaboration.

\section{B Interpreting the Right to Participate}

While civil parties have the right to participate and be heard during the proceedings, views differ as to the extent of that participation. This touches upon the much deeper issue of how far the interest of a third party should be accommodated at the expense of the rights of the accused. ${ }^{85}$ This debate is currently being played out at the ECCC with regard to pre-trial detention hearings.

At the hearing on the appeal by Nuon Chea against a provisional detention order, the defence objected to the involvement of civil parties at the pre-trial phase. ${ }^{86}$ The defence asserted that civil party participation under Rule 23 presupposed an interest in the outcome of the proceedings, and

81 Boyle, above n 2, 308.

82 Internal Rules, r 23(8)

83 Internal Rules, r 23(9).

84 Boyle, above n 2, 309.

85 Doak, above n 61, 295.

86 Decision on Civil Party Participation in Provisional Detention Appeals (20 March 2008) 002/19-09-2007ECCC/OCIJ (PTC01) para 5 (Pre-Trial Chamber, ECCC). 
consequently a restrictive approach to such participation should be adopted. They conceded that a civil party was justified in participating when they had an interest in the outcome of the decision. However, they argued that civil parties did not have an interest in preliminary decisions, such as pretrial detention, and as such should be barred from participating. ${ }^{87}$ The defence relied on examples from the ICC where victims are entitled to participate only when they have a personal interest in the outcome of the proceedings. ${ }^{88}$ However, the status of victims at the ICC differs from that at the ECCC. The ICC has granted victims active participation rights, but they are not full parties to the proceedings as civil parties are at the ECCC. Consequently, the analogy was probative at best.

The prosecution argued in favour of civil party participation at the pre-trial phase, submitting that Rule 23 did not limit the meaning of "proceedings" and must therefore be interpreted to include the pre-trial phase. They also argued that international criminal practice is favourable towards victim participation in the investigative phase. ${ }^{89}$ The civil parties themselves submitted that Rule 23 conferred on them the right to participate in all stages of the proceedings. They expressed a desire to address the court on how the charged person could affect society if he were to be released from pretrial detention. ${ }^{90}$

The Pre-Trial Chamber accepted the arguments submitted by the prosecution and civil parties and rejected the requests of the charged person to exclude civil parties from pre-trial proceedings. The Chamber stated that the Internal Rules are "clear in [their] wording that Civil Parties can participate in all criminal proceedings..." and that "Civil Parties have active rights to participate starting from the investigative stage." 91

This was heralded as a landmark decision by victims' rights activists. The International Federation for Human Rights stated that the decision "sets an important precedent in the interpretation of the rules applicable to civil party participation before the ECCC." 92 Efforts by the Pre-Trial Chamber to grant broad participatory rights to civil parties must be applauded. However, victim participation before international tribunals remains in its nascent stage. The extent of civil party participation continues to be uncertain as the ECCC feels its way forward in this emerging area of international criminal law. The fragility of the civil parties' position was demonstrated in July 2008 when the Pre-Trial Chamber issued a series of oral judgments prohibiting civil parties

87 Ibid.

88 Rome Statute above n 72, art 68(3).

89 Decision on Civil Party Participation in Provisional Detention Appeals (20 March 2008) 002/19-09-2007ECCC/OCIJ (PTC01) para 6 (Pre-Trial Chamber, ECCC).

$90 \quad$ Ibid, para 7

91 Ibid, para 36.

92 International Federation for Human Rights Cambodia Tribunal Allows Victims of Khmer Rouge to Participate in Proceedings (28 March 2008) www.fidh.org (accessed 9 August 2009). 
from speaking in person during pre-trial appeals. The Pre-Trial Chamber relied on Rule 77(10) which they interpreted as prescribing that only lawyers for civil parties, not the civil parties themselves, have the right to make brief observations during pre-trial appeals. ${ }^{93}$ This decision may prove to be prohibitively restrictive on civil parties who choose to represent themselves at the Tribunal. While the ECCC has incorporated a progressive stance on victim involvement, questions remain over how far this participation can extend.

These tensions are predictable in such a new area of law and should not dampen the real innovation of victim participation at the ECCC. No other international criminal tribunal has granted victims the right to be joined as full parties to the proceedings. Victims are now seen as an equally important stakeholder in the criminal process before international criminal justice. However, despite a comprehensive integration of victims into proceedings, the ECCC continues to struggle with a negative public perception and inadequate access to proceedings. The following section explores how this new form of victim participation may help to mitigate the scepticism fostered by in camera pre-trial proceedings.

\section{MEASURES TO INCREASE PUBLIC ACCESS THROUGH VICTIM PARTICIPATION}

Victims of the Khmer Rouge are intimately connected through their communities to the wider social goals of the ECCC. Their involvement in proceedings is extensive and an exciting innovation in the context of international criminal justice. This paper now explores the ways in which civil parties may use their position to increase public access and the dissemination of information at the ECCC. It will also provide a brief note on balancing the rights of victims and the accused.

\section{A The Potential Contribution of Civil Parties}

Civil parties have an important contribution to make to increasing public accessibility to proceedings and information at the ECCC which at present is being underutilised. Civil parties have existing networks and channels of dissemination which would provide an easy and effective link to the Cambodian population. Allowing civil parties the right to disclose information during the pretrial phase would bring much needed openness and legitimacy to the ECCC process.

Civil parties become full parties to the proceedings at the Tribunal. This includes the right to access information during the investigation. Internal Rule 86 states that: ${ }^{94}$

[a]t all times, the Co-Prosecutors and the lawyers for the other parties shall have the right to examine and obtain copies of the case file, under supervision of the Greffier ${ }^{95}$ of the Chamber, during working days and subject to the requirements of the proper functioning of the ECCC.

93 Written Version of Oral Decision of 1 July 2008 on the Civil Party's Request to Address the Court in Person (3 July 2008) 002/19-09-2007-ECCC/OCIJ(PTC03) para 3 (Pre-Trial Chamber, ECCC).

94 Internal Rules, r 86. 
Consequently, civil parties have access to information concerning in camera proceedings before the Co-Investigating Judges and the Pre-Trial Chamber which could provide an important avenue for increasing transparency and the dissemination of information to the public.

Pursuant to Internal Rules 56 and 54, the Co-Investigating Judges and the Co-Prosecutors have the ability to increase the transparency of the ECCC by disclosing information to the public. This paper suggests that the ECCC would greatly benefit from conferring similar rights to civil parties. Rule 54 concerning public information by the Co-Prosecutors states that: ${ }^{96}$

Mindful of the need to ensure that the public is duly informed of ongoing ECCC proceedings, the Co-

Prosecutors may provide the public with an objective summary of the information contained in [their]

submissions, taking into account the rights of the defence and the interests of Victims, witnesses and any

other persons mentioned therein, and the requirements of the investigation.

Amending the Internal Rules to include a similar provision relating to civil parties has the potential to greatly increase transparency at the ECCC. Provided disclosures by civil parties do not violate confidentiality or protection orders, such an amendment should not be problematic. It is certainly an easier road than attempting to reverse the presumption of in camera pre-trial proceedings. It would also put the task of duly informing the public into the hands of parties who have a direct interest in conveying information to a wider audience. Presently, this function is being performed solely by the Co-Investigating Judges and the Co-Prosecutors whose interests are necessarily focused on the process of the trial itself, rather than its broader social impact.

Institutional differences may lie behind the decision to grant a positive right of disclosure to the Co-Investigating Judges and the Co-Prosecutors alone. The Office of the Co-Investigating Judges and the Office of the Co-Prosecutors are organs of the ECCC. Their staff are employed by the Tribunal. Firstly, this in theory means that all staff have met high minimum standards for employment. ${ }^{97}$ The Tribunal may also control who has access to confidential information within these two offices. Secondly, employees can be held directly accountable for misconduct by either the UN Staff Regulations and Rules in the case of international personnel, or the appropriate national authorities in the case of national staff members. ${ }^{98}$ However, lawyers for the civil parties are not ECCC employees. In the case of misconduct or an abuse of this hypothetical power of disclosure, the ECCC would not have the same avenues of recourse available. However, Rule 35(1) does provide sanctions for anyone who interferes with the administration of justice through the

Greffier acts as registrar or recorder for the Chamber.

Internal Rules, $r 54$.

Although we know from the UNDP Special Audit in 2007 that many domestic staff did not meet minimum job requirements, see above $\mathrm{n} 31$.

Internal Rules, rr 6(4) and (5). 
disclosure of confidential information in violation of an order of the Co-Investigating Judges or the Chambers. ${ }^{99}$ Furthermore, any amendment to the Internal Rules granting civil parties rights to disclose information would necessarily contain limitations and sanctions for abuse. Consequently, the difference in status between the civil party lawyers and the Co-Investigating Judges and the CoProsecutors should not prohibit the granting of greater disclosure rights to civil parties.

However, such an amendment may not materialise.. The ECCC has been reluctant to amend its Internal Rules based on previous recommendations. With or without an amendment, a general effort to focus on increasing dialogue between civil parties and the wider community via civil society organisations will help to open the proceedings and encourage public engagement with the ECCC. By ensuring that civil parties participate in collaboration with their wider communities, a contribution may be made to transparency in the interim within existing boundaries of disclosure, for example, through civil parties discussing the non-confidential elements of their participation with others.

Civil society projects such as the public forums held by the Centre for Social Development (CSD) are one medium through which the civil party experience may be utilised. CSD have conducted a series of public forums throughout Cambodia entitled "Justice and National Reconciliation." The main goals of these forums are: ${ }^{100}$

(i) to disseminate information regarding the KR years, the ECCC, processes of just peace, healing, reconciliation, (ii) to help manage the expectations of the participants as to what the ECCC can achieve in terms of peace, justice and reconciliation, and ultimately (iii) to create a multiplier effect in these participants as ambassadors to their families and neighbours.

At present, the forums bring together representatives from the ECCC, civil society organisations, and members of local communities. As proceedings continue, civil parties may become an important voice at these forums as well. At the time of writing, there were 28 civil parties approved by the Victims' Unit at the ECCC, and over 1000 applications waiting to be processed. ${ }^{101}$ As these numbers continue to grow and civil parties begin to actively participate in the proceedings, their experience will be a powerful voice.

In their current form, the Internal Rules do not acknowledge the significant interest victim participants have in the wider process of national reconciliation. In 1961, Garfinkel argued that the

99 Internal Rules, r 35(1)(a).

100 Center for Social Development, Phnom Penh "Public Forum on "Justice and Reconciliation"(28 May 2007) Press Release,.

101 Information unpublished on the ECCC website at the time of writing. 
success of a criminal trial should not be determined by the number of guilty verdicts, but instead measured by the wider social impact of the process. ${ }^{102}$ Cockayne agreed, stating that: ${ }^{103}$

Verdicts in criminal trials may not reflect the entire social outcome: an acquitted defendant may nevertheless walk away socially tainted, just as some defendants may benefit socially from conviction.

This is undoubtedly true of the ECCC process. The ability of the ECCC to fulfil its wider mandate of contributing to national reconciliation will be dependant on broad social acceptance of the process. Cambodia already carries a legacy of failed attempts at feigning justice in the aftermath of the Khmer Rouge.

In 1979, Pol Pot and Ieng Sary were hastily brought to trial at the People's Revolutionary Tribunal established in Phnom Penh by the newly installed, Vietnamese-controlled Government. The proceedings are widely regarded as a show trial. The rules governing the court and the law to be applied were unclear, and no attempt at impartiality or fairness was made. The defence lawyer for the two accused called her clients "criminally insane monsters" and demanded that they be condemned to death. ${ }^{104}$ The Court sentenced Pol Pot and Ieng Sary to death in abstensia. However, neither accused was ever brought to justice. Pol Pot died in his bed on the Thai border in 1999, and Ieng Sary was a free man until his indictment by the ECCC on 12 November 2007. To add insult to injury, Ieng Sary is now attempting to use the 1979 show trial and the principle of double jeopardy to avoid prosecution at the ECCC, claiming that he has already been tried and punished for the crimes he committed. ${ }^{105}$ The severe lack of transparency, legitimacy, or concern for due process has tainted the legacy of the People's Revolutionary Tribunal. The aftermath demonstrates that a guilty verdict alone will not secure public acceptance or satisfy the need for justice in Cambodia.

Again in 1996, Ieng Sary was officially pardoned for his crimes by Prime Minister Hun Sen. At the time he was a war-lord controlling the gem mines on the Thai-Cambodian border and still connected with the remaining faction of the Khmer Rouge led by Pol Pot. ${ }^{106}$ Shortly after in 1998, the Government also granted amnesties to Nuon Chea and Khieu Samphan. At a press conference honouring the occasion, the two men issued a brief and ambiguous apology for their sins. ${ }^{107}$ In the

102 Harold Garfinkel "Conditions of successful degradation ceremonies" (1956) 61 Am J Sociology 420.

103 Cockayne, above n 7, 457.

104 David Chandler "Will There Be a Trial for the Khmer Rouge?" (2000) 14 Ethics Int Aff 67, 72.

105 See Ieng Sary's Submissions, above n 33.

106 Shawcross, above n 5, 51.

107 Chandler, above n 104, 69. 
wake of Ieng Sary's 1996 pardon, he confided in a French television show: "Honestly, in my heart the wound is healed." 108 It is obvious the victims of the Khmer Rouge have not derived the same level of satisfaction from the de facto justice employed by the Cambodian government. ${ }^{109}$ To ensure the ECCC does not meet the same fate, its proceedings must be perceived as impartial, independent, and focused on the broader goals of social healing and upholding the rights of victims. Submitting the five accused to the full and proper weight of the law, which includes guaranteeing due process rights, is also an essential condition for legitimate trials.

\section{B Balancing the Rights of Victims and the Accused}

In both civil and common law, and indeed in international criminal justice, confusion prevails about rights protection: "where do the victim and the accused person stand relative to each other and the interests of the State?"110 In the context of the Khmer Rouge regime and such egregious crimes, the kind of violence Kant called "radical evil", Hannah Arendt has asked:111

What does "justice" mean, in the face of so much horror? ... Should we begin with the presumption of innocence or the assumption of guilt? Are there such things as unforgivable crimes?

Indeed, these sentiments have recently been expressed at public hearings before the Pre-Trial Chamber at the ECCC. At the appeal of a pre-trial detention order, Duch's lawyer submitted that his client's human rights had been violated because of the time he had spent at a military jail before being transferred to the ECCC detention facility. ${ }^{112}$ This argument was met with a wave of laughter from the Cambodians in the public gallery. It was overwhelmingly comical that this man, who directed the S21 prison which oversaw the deaths of tens of thousands of people, would claim that his human rights had been violated. ${ }^{113}$ It was a moment which has been described as one of perfect irony which "captured every aspect of the horror, hope, scepticism and disbelief" surrounding this concept of justice. ${ }^{114}$

108 Chandler, above n 104, 69.

109 Chandler, above n 104, 73.

110 Mark Findlay "Synthesis in Trial Procedures? The Experience of International Criminal Tribunals" (2001) 50 Int \& Comp L Q 26, 50.

111 Chandler, above n 104, 67-68; Carlos Nino Radical Evil on Trial (Yale University Press, New Haven, 1996) 135; Hannah Arendt The Human Condition (University of Chicago Press, Chicago, 1958) 241.

112 See Decision on Appeal Against Provisional Detention Order of Kaing Guek Eav alias "Duch" (3 December 2007) 001/18-07-2007-ECCC-OCIJ (PTC01) (Pre-Trial Chamber, ECCC).

113 Appeal of Pre-Trial Detention Order by Kaing Guek Eav (alias Duch) (20 Novemebr 2007). Actual footage of the hearing is available online at www.cambodiatribunal.com.

114 Vinita Mohan "Social Memory and Civil Society in Post-Conflict Cambodia" (ASIA Fellow, July 2007January 2008) (unpublished) 33. 
However, commentators at the ECCC have begun to stress the importance of fundamental due process rights, such as the presumption of innocence, in the face of increasing victim involvement. Victor Koppe, a defence attorney for one of the Khmer Rouge leaders has stated that "[t]he question is whether or not everything in this tribunal is institutionalised in such a way that only guilty verdicts can come."115 Although the atrocities of the Khmer Rouge period are difficult to comprehend, and while an enormous gap remains between "what actually happened in the 1970s and how precisely these events can be 'objectively' reconstructed"116 in a criminal trial, this question remains valid and vital. The ECCC has broader goals than delivering verdicts. In addition to national reconciliation, the ECCC will also serve as an exemplary institution, demonstrating the application of the rule of law and developing the capacity of the domestic judiciary. ${ }^{117}$ Victims' rights have taken centre stage in recent years, but must not be entertained at the expense of fundamental due process rights of the accused. However, as domestic and international developments show, the two are not mutually exclusive.

Victim participation in criminal proceedings is a settled principle in many domestic civil law jurisdictions. In Germany, for example, victims may act as subsidiary prosecutors with rights to legal representation and active participation throughout the process. ${ }^{118}$ The partie civile or civil party model operates in both France and Belgium. ${ }^{119}$ However, the ECCC is the first forum to apply this model in an international criminal law context. Consequently, the traditional justifications and limitations of victim participation in domestic jurisdictions cannot be directly applied to the ECCC. In the trial of serious international crimes, the stakes are much higher than in ordinary criminal cases. It is important to contextually reassess where the victim and the accused stand relative to each other, the interests of the public, and the power of the State. ${ }^{120}$

This concept is encapsulated in the principle of equality of arms which requires that no substantial disadvantage exist between one party and another when presenting his or her case in court. ${ }^{121}$ Critics of civil party involvement have argued that active victim participation upsets the delicate balance between the power of the State and the rights of the accused. Such criticisms are usually reasoned from common law principles based on a bipartisan adversarial trial. ${ }^{122}$ Common

115 Seth Mydans "Tribunal in Cambodia gives Victims a Voice" (17 June 2008) The Global Edition of the New York Times 10.

116 Chandler, above n 104, 68.

117 Civil Society Recommendations on Transparency Measures, above n 50, 1.

118 Doak, above n 61, 308.

119 Doak, above n 61, 310.

120 Findlay, above n 110, 50.

121 Findlay, above n110, 48.

122 ADHOC, above n 4, 38. 
law criminal procedure, in its purest form, is a type of public law, punishing crimes which are serious enough to impact upon the wider social good and stripping those offences of their interpersonal character. ${ }^{123}$

This is not the occasion to delve into a comparison of the tensions between common law and civil law criminal procedure. Suffice it to note that an inquisitorial process escapes many of the difficulties of a common law trial in terms of victim participation by virtue of the fact the proceedings are judge-led, rather than party-led. Civil law criminal procedure is a unitary process where public and private elements of an offence are pursued simultaneously under far more judicial mediation than in the common law system. ${ }^{124}$

Concerns raised by common law jurist should not, however, be dispensed with on the basis of these tensions alone, particularly in the case of the ECCC. International criminal justice has developed primarily in common law-dominated forums and invariably, the current form of international criminal procedure will reflect this. International procedure is supplementary to Cambodian criminal procedure at the ECCC, but will trump domestic law in the case of an inconsistency between the two. ${ }^{125}$ Indeed, adversarial proceedings have already been enshrined as a fundamental principle of its operation. ${ }^{126}$

However, in terms of an approach to victim participation, it is unlikely that Cambodia's civil law system will come into conflict with international rules given recent developments in the field of international criminal law. The recognition of active participatory rights for victims at the ICC demonstrates that the involvement of civil parties at the ECCC is congruent with the current state of international criminal law. Perhaps more telling is the development of international criminal justice in the common law based ICTY and ICTR which also indicated that active victim participation can function alongside fundamental due process rights of the accused, even in adversarial proceedings.

Exploring efforts to increase public access to proceedings at the ECCC need not benefit victims alone. The European Court of Human Rights held that the public character of proceedings "protects

123 Andrew Ashworth "What Victims of Crime Deserve" (Paper presented to the Fulbright Commission on Penal Theory and Penal Practice, University of Stirling, September 1992) as cited in M Cavadino and J Dignan "Towards a Framework for Conceptualising and Evaluating Models of Criminal Justice from a Victim's Perspective" 4(3) IRV 153.

124 Doak, above 61, 308.

125 Agreement, above 31, art 12(1).

126 Internal Rules, r 21. 
[all] litigants against the administration of justice in secret with no public scrutiny."127 The UNDHR also secures the Accused's right to transparent proceedings. Article 11 states that: ${ }^{128}$

[e]veryone charged with a penal offence has the right to be presumed innocent until proved guilty according to law in a public trial at which he has had all the guarantees necessary for his defence.

Greater public access at the ECCC will benefit all parties, as well as the wider community. It will assist in facilitating external monitoring of proceedings and ensure the process is open to objective comment and critique. In so doing, transparency measures will contribute to creating an impartial and independent tribunal where the rights of all parties are upheld.

The disclosure of information must be fair and comprehensive. If empowered to do so, civil parties will naturally disseminate information relevant to national reconciliation and victims rights. However, disclosing information regarding the rights of the accused is also essential in creating true transparency and facilitating accurate monitoring of proceedings. Consequently, efforts to increase transparency through victim participation must be sought alongside continued pressure to open proceedings to the public. It may also be beneficial to afford disclosure rights to the Co-Defence Lawyers as well.

\section{CONCLUSION}

The impartiality of the ECCC has come under fire in the past few years. The instability of the domestic judicial system and allegations of corrupt practices have severely tainted the integrity of the Tribunal. The civil law foundation of the ECCC has also created unique challenges by importing a presumption of in camera pre-trial proceedings. Exceptions to this presumption have not been utilised adequately and for this reason, there is a lack of access to proceedings before the Tribunal, and insufficient information disseminated to the public.

While it is easy to become cynical or despondent about the process, this attempt at long-awaited justice needs support and constructive criticism. It is important that the positive innovations at the ECCC be acknowledged and developed. While addressing the shortfalls of the ECCC as it stands, this paper also offers suggestions as to how victim participation may combat the most difficult challenge facing the Tribunal.

The Internal Rules of the ECCC have paid respect to Cambodian procedure by allowing the full participation of victims as civil parties. They have also made "intelligent reference" to alternative procedures to facilitate the effective participation of a large number of victims, such as allowing collective representation. ${ }^{129}$ The participatory rights of civil parties have also been interpreted

127 Human Rights Watch, above n 3, 11.

128 Universal Declaration of Human Rights, above n 64, art 11.

129 Boyle, above n 2, 310. 
broadly by the Pre-Trial Chamber, although these rights remain fragile. This demonstrates a commitment from the Chambers to encouraging the participation of victims and recognising the important contribution they will make to the success of the Tribunal.

However, the ECCC has not recognised or utilised the connection between victims and the broader goal of national reconciliation. The Internal Rules allow victims to support the prosecution and seek reparations, but not to engage with the wider community. The ECCC has recognised the importance of creating a transparent and accountable process. It has established links between the Tribunal, victim communities, and the general public through granting disclosure rights to the CoInvestigating Judges and Co-Prosecutor. It also operates an out-reach programme and consults with civil society organisations. However, civil parties have not been included in this process.

Existing international criminal tribunals have also shied away from institutionalising the connection between victims and national reconciliation. Most have not even recognised victims beyond their capacity as witnesses. However, common law procedure allows for far greater public access to proceedings, and consequently the need for creative transparency measures has not been at issue. At the ECCC, transparency is a very real challenge. It is one of the first times international criminal justice has been applied in a domestic civil law context. Consequently, it requires more than a simple importation of existing rules. This paper suggests that the answer may lie in the civil law context itself. Victim participation is still in its nascent stage on the international scene. However, Cambodia has the advantage of settled principles of civil party involvement drawn from the French model.

Civil parties have access to outside support and a wide community network. They also have the personal motivation to contribute to the process of social healing in Cambodia. By granting civil parties the right to disseminate information, the ECCC is putting the task of increasing public access into the hands of parties who have a real interest in doing so. The involvement of victims in this way can strengthen the perception of impartiality and independence at the ECCC. 